\title{
Paisagem cultural e políticas públicas do Patrimônio Mundial no Brasil (2012-2019)
}

\author{
Leonardo Civale ${ }^{1}$ \\ Walkiria Maria de Freitas Martins ${ }^{2}$
}

\begin{abstract}
Resumo: $\mathrm{O}$ conceit o de paisagem cultural, historicamente associado à ciência geográfica, foi interpretado como uma tipologia do Patrimônio Mundial e incorporado pelo Comitê da UNESCO em 1992. O artigo objetiva a compreensão deste conceito e das tipologias dele derivadas e operadas pela UNESCO, nos dois casos ocorridos no Brasil: "Rio de Janeiro: paisagens cariocas entre o mar e a montanha" e "Conjunto Moderno da Pampulha". Após a análise dos dossiês de candidatura ao título de Patrimônio Mundial foi possível identificar os usos da memória e as construções narrativas derivados da confluência do conceito de paisagem cultural e das políticas públicas dos campos do patrimônio brasileiro e mundial. O resultado são os discursos que consagraram esses dois sítios brasileiros como paisagens culturais excepcionais, mundialmente reconhecidas.
\end{abstract}

Palavras-chave: Patrimônio Mundial; paisagem cultural; políticas públicas; narrativas; memória.

\section{Paisaje cultural y políticas públicas del Patrimonio Mundial en Brasil (2012-2019)}

Resumen: El concepto de paisaje cultural, históricamente asociado con la ciencia geográfica, fue interpretado como una tipología del Patrimonio mundial e incorporado por el Comité de la UNESCO en 1992. El artículo tiene como objetivo entender este concepto y las tipologías derivadas de él y operadas por la UNESCO, en los dos casos ocurridos en Brasil: "Río de Janeiro: paisajes cariocas entre el mar y la montaña" y "Conjunto Moderno da Pampulha". Tras analizar los expedientes de solicitud para el título de Patrimonio Mundial fue posible identificar los usos de la memoria y las construcciones narrativas derivadas de la confluencia del concepto de paisaje cultural y políticas públicas de los campos del patrimonio brasileño y mundial. El resultado son los discursos que consagraron estos dos sitios brasileños como paisajes culturales excepcionales, reconocidos en todo el mundo.

Palabras-clave: Patrimonio Mundial; paisaje cultural; políticas públicas; narrativas; memoria.

\section{Cultural landscape and public policies of World Heritage in Brazil (2012-2019)}

\begin{abstract}
The concept of cultural landscape, historically associated with geographical science, was interpreted as a typology of the World Heritage site and incorporated by the UNESCO Committee in 1992. The article aims to understand this concept and the typologies derived from it and operated by UNESCO, in the two cases that occurred in Brazil: "Rio de Janeiro: carioca landscapes between the sea and the mountain" and "Conjunto Moderno da Pampulha". After analyzing the dossiers of application for the title of World Heritage it was possible to identify the uses of memory and narrative constructions derived from the confluence of the concept of cultural landscape and public policies of the fields of Brazilian and world heritage. The result is the discourses that consecrated these two Brazilian sites as exceptional cultural landscapes, recognized worldwide.
\end{abstract}

Keywords: World Heritage; cultural landscape; public policies; narratives; memory.

\section{(c) (1) $(9)$}

DOI: https://doi.org/10.26512/patryter.v4i7.30394

Como citar este artigo: Civale, L.; Martins, W. M. F. (2021). Paisaje cultural y políticas públicas del Patrimonio Mundial en Brasil (2012-2019). PatryTer - Revista Latinoamericana e Caribenha de Geografia e Humanidades, 4 (7), 90 106. DOI: https://doi.org/10.26512/patryter.v4i7.30394

Recebido: 29 de março de 2020. Aceite: 17 de agosto de 2020. Publicado: 01 de março de 2021.

${ }^{1}$ Professor do Departamento de Geografia da Universidade Federal de Viçosa. ORCID: https://orcid.org/0000-00030048-8336. E-mail: civale@ufv.br

2 Professora de História do Colégio de Aplicação João XXIII da Universidade Federal de Juiz de Fora (MG) e doutoranda em História na Universidade Federal do Estado do Rio de Janeiro (UNIRIO). ORCID: https://orcid.org/0000-0003-3216-7051. E-mail: walkiriafreitas@yahoo.com.br 


\section{Introdução}

"A paisagem é um bem indispensável para um equilibrio da vida. Ela responde aos imperativos de territorialidade e da pertença, isto é, às necessidades de inserirmos nossa trajetória biográfica não apenas num eixo temporal, mas também espacial. Essa necessidade é cultural. A paisagem é indispensável para a vida consciente, para a qualificaşão de nossa interação existencial com o mundo objetivo". (Meneses, 1999, p. 59).

Desde o momento em que a discussão sobre a manifestação de fenômenos culturais no espaço começou a ganhar corpo no Brasil, nos dois últimos decênios do século XX, muita tinta tem sido gasta sobre o conceito de paisagem (Corrêa \& Rosendahl, 1998). Temas como as origens do conceito de paisagem, sua importância para a definição da geografia enquanto ciência e sua operacionalidade como uma das categorias de análise da ciência geográfica dominaram uma das vertentes da cena intelectual da geografia entre o final do século XX e o início do século XXI (Besse, 2006). O presente artigo não declina de participar da discussão acadêmica sobre o conceito de paisagem como categoria de análise na geografia, sobretudo, por não duvidar da importância do debate científico para a promoção e divulgação do conhecimento. No entanto, o objetivo aqui é refletir sobre a operacionalização do conceito de paisagem, em suas diferentes tipologias pela UNESCO (Unesco, 1994) como base conceitual para as políticas públicas de construção, preservação e conservação do patrimônio cultural. Portanto, o foco do trabalho é a relação entre o conceito de paisagem cultural, em sua dimensão histórica e espacial e a ideia de patrimônio cultural (Lowenthal, 2008). Para ser preciso, o artigo se propõe a compreender a paisagem cultural como o resultado de uma miríade de experiências históricas e espaciais que representam a herança a continuidade e a diversidade cultural da ocupação humana em toda a superfície terrestre (Besse, 2014). O conceito de paisagem cultural pode ser visto como fruto da engenhosidade e criatividade humanas na ocupação histórica dos diferentes lugares, bem como, como política pública, envolvendo o conceito de cidadania, na valorização, preservação e conservação da diversidade cultural dos lugares (Bortolloto, 2003).

Normalmente, a paisagem é definida pelo senso comum, como tudo aquilo relativo ao que se vê ou, como o cenário que se descortina ao olhar do observador a partir de uma perspectiva ou ângulo de observação. No entanto, em um contexto acadêmico ou como núcleo central de políticas públicas de patrimônio, a paisagem pode, ou melhor, deve ser dimensionada dentro de um quadro conceitual que seja capaz de revelar a sua diversidade cultural e complexidade. Tal complexidade, entretanto, não se manifesta através da objetividade daquilo que se pode ver, antes, é o resultado da ação de sujeitos históricos concretos sobre um quadro natural (Besse, 2014). Quando dizemos da complexidade da paisagem não estamos nos referindo a sua dupla natureza enquanto um objeto natural e, ao mesmo tempo, uma expressão simbólica (Cosgrove, 1998). Tampouco, estamos nos rendendo à clivagem clássica entre o conceito de paisagem natural e paisagem cultural. A paisagem nos interessa como uma realidade concreta e complexa, resultado da ação humana sobre o ambiente, fruto de práticas culturais de atores históricos de carne e osso (Besse, 2014). A paisagem cultural é, portanto, o resultado de valores subjetivos dos diversos agrupamentos humanos sobre realidades locais concretas (Borttoloto, 2011).

Saltam aos olhos os exemplos de paisagens como conjuntos de objetos naturais e culturais que guardam vestígios não apenas de diferentes tempos históricos, mas, sobretudo, de distintos grupos identitários (Cosgrove, 1998). Partimos dessa ideia de complexidade e diversidade cultural porque a transformação do ambiente natural pela ação das sociedades, aliada à incontornável historicidade da ocupação humana dos lugares, viria a permitir o inventário das diversas experiências históricas, bem como, a utilização do conceito de paisagem cultural como patrimônio, em suas distintas tipologias.

O Comitê de Patrimônio Mundial da UNESCO, no ano de 1992, em uma reunião em Santa Fé, no Novo México, incorporou a tipologia de paisagem cultural como um dos vieses para a definição de lugares como Patrimônios Mundiais. Tal tipologia, extremamente abrangente, teve o condão de construir e/ou recortar da realidade concreta paisagens culturais como fruto da ocupação histórica dos mais diferentes lugares. Consequentemente, isso possibilitou instrumentalizar, do ponto de vista conceitual e político, os processos de patrimonialização de diferentes lugares do planeta.

A inclusão na Lista do Patrimônio Mundial da UNESCO tem, certamente, um caráter, eminentemente simbólico, ainda que seja resultado de um longo e demorado processo, amparado por uma série de documentos que compõem um 
elaborado dossiê. A Lista, mas, sobretudo, os dossiês têm se revelado excelentes materiais empíricos, não apenas sobre as políticas de Patrimônio Mundial, como também dos órgãos nacionais de proteção ao patrimônio. Além disso, o conjunto de documentos e argumentos arrolados nos dossiês revela um complexo cenário geopolítico pós-colonial e a discussão dos limites do universalismo iluminista (Borttoloto, 2011).

$\mathrm{O}$ presente artigo se divide em três partes. Visando a compreensão do conceito de paisagem cultural e das tipologias dele derivadas e, operadas pelo Comitê do Patrimônio Mundial da UNESCO, optamos por uma análise histórica do conceito de paisagem e sua interpretação pelo saber geográfico. Em um segundo momento, procuramos mostrar como o conceito de paisagem cultural, em virtude de sua natureza histórica e espacial, foi interpretado como uma tipologia do patrimônio cultural e incorporado pela UNESCO. A Convenção de 1972 é o documento que orienta as ações do Comitê do Patrimônio Mundial, mas, seu entendimento e operacionalização mudam frequentemente. Um exemplo dessas mudanças foi a institucionalização da tipologia de paisagem cultural em 1992, a partir de uma preocupação com a proteção das paisagens, já expressa na Convenção desde 1972.

Por fim, analisamos dois exemplos concretos de aplicação da tipologia das paisagens culturais: as outorgas dos títulos de Patrimônio Mundial à cidade do Rio de Janeiro em 2012, na reunião de São Petersburgo, na Rússia e ao "Conjunto Moderno da Pampulha", localizado em Belo Horizonte, Minas Gerais, na reunião em Istambul, na Turquia, em 2016. Esses são os dois sítios brasileiros reconhecidos como Patrimônios Mundiais e listados na tipologia paisagem cultural. A respeito deles, propomos uma análise das narrativas que compõem seus dossiês de candidatura ao título de Patrimônio Mundial, destacando, precisamente, os discursos de valoração e as memórias mobilizadas para que eles fossem reconhecidos como paisagens culturais brasileiras.

Figura 1: Cidade do Rio de Janeiro: mapa de localização, foto e imagem de satélite

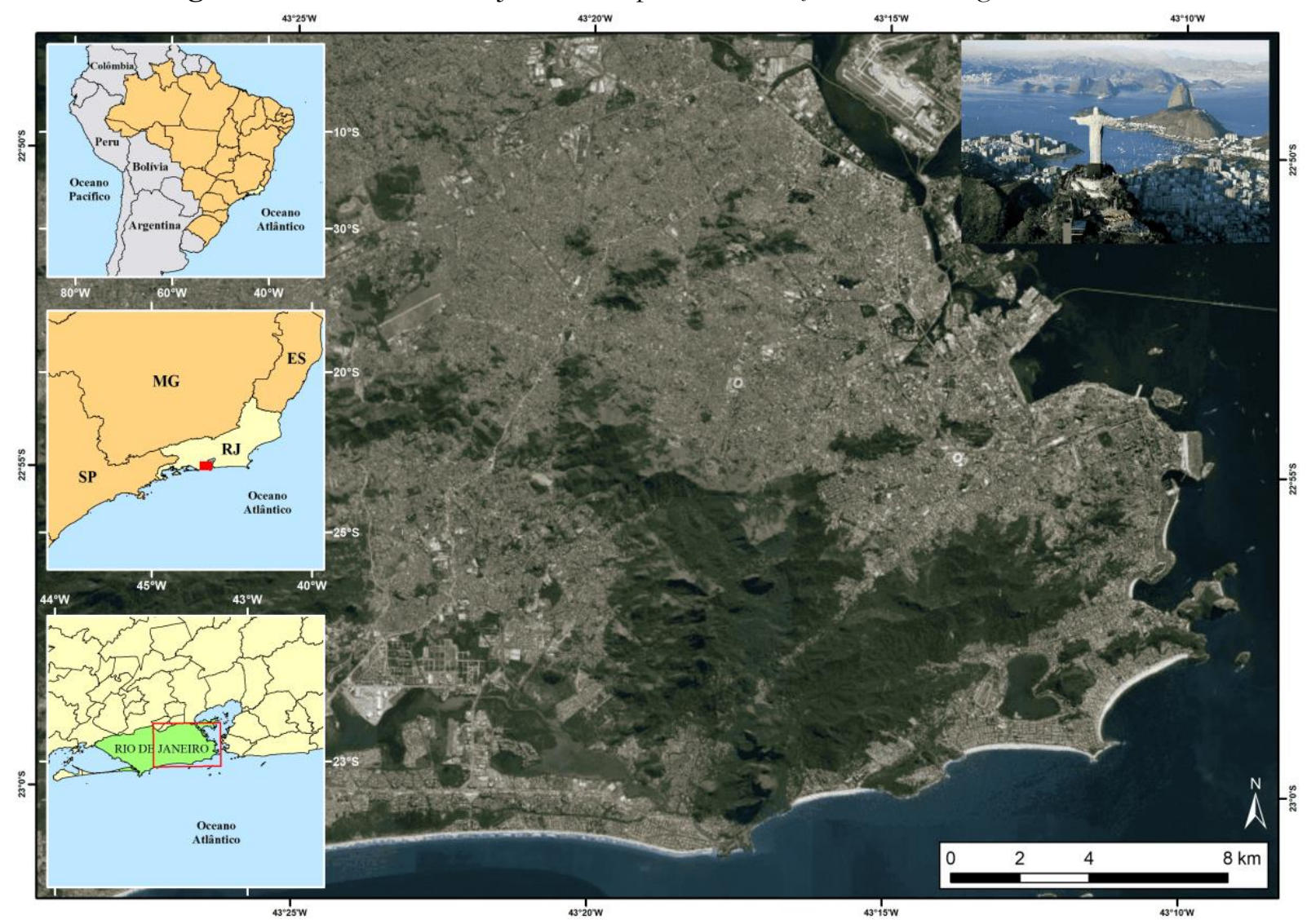

Fontes: Elaborado com mapas políticos do IBGE; Imagem de satélite do Google Earth e imagem da cidade, recuperada de http://visit.rio/en/que fazer/christtheredeemer/. Consultas em 15/07/2020.

Organização: Dr. Leonardo Civale e Ms. Walkiria Martins. Elaboração: Neuman Assis. 
Figura 2: Bairro Pampulha, Belo Horizonte (MG): mapa de localização, foto e imagem de satélite

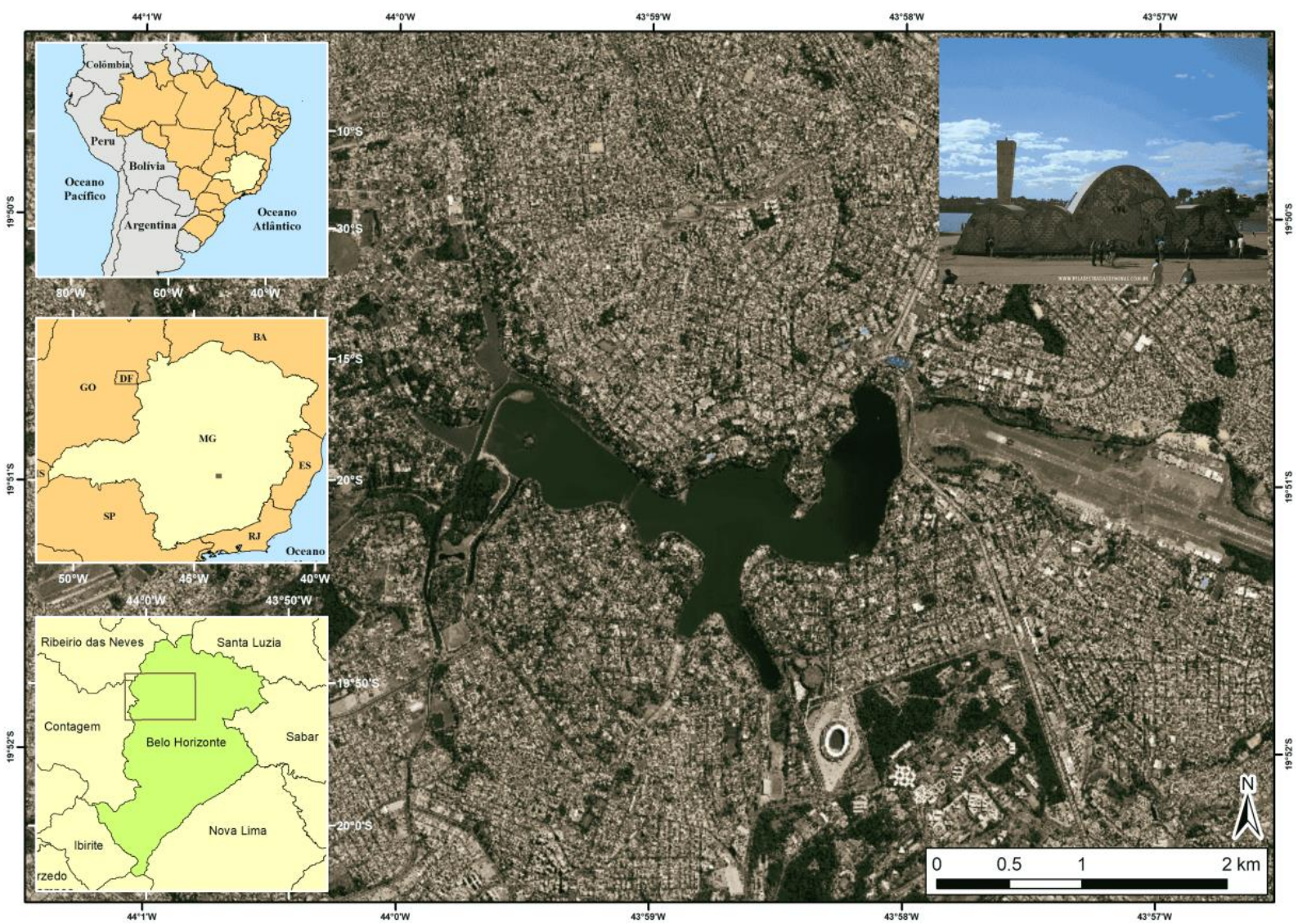

Fonte: Elaborado com mapas políticos do IBGE; agem de satélite do Google Earth e imagem da cidade recuperada de http://pelasestradasdeminas.com.br/. Consultas em 15/07/2020.

Organização: Dr. Leonardo Civale e Ms. Walkiria Martins. Elaboração: Neuman Assis

Certamente, a historiografia não deve ser reduzida a narrativas históricas, uma vez que a historiografia ultrapassa a mera narrativa. Em outras palavras, a narrativa é apenas um dos componentes da operação historiográfica. Esta implica em análise e crítica das fontes, distanciamento crítico das fontes, diálogo com a teoria da história, compromisso com veracidade dos fatos e, evidentemente, metodologia de pesquisa.

No artigo se presta uma homenagem à metodologia não por mero capricho, antes para trazer à luz a construção de narrativas sobre $\mathrm{O}$ patrimônio. Tal metodologia que se dedica a escovar a história ou, nesse caso, a narrativa à contrapelo tem por objetivo revelar a essência dos processos de patrimonialização, ou seja, mostrar que o patrimônio é, antes de tudo, uma construção narrativa, ainda que esta narrativa tenha o condão de, se bem aplicada, reverenciar a memória da população e não apenas a memória dos vencedores.

\section{O conceito de paisagem}

A partir de 1992 os seis primeiros critérios da Convenção de 1972, aplicáveis ao patrimônio cultural, passaram a incorporar, também, as paisagens culturais (Ribeiro, 2007, p. 41). O Comitê do Patrimônio Mundial, procurando ampliar a salvaguarda, preservação e conservação do patrimônio cultural, estabeleceu como tipologia desse patrimônio, o conceito de paisagem cultural, o qual, incorporaria os trabalhos resultantes da combinação de elementos culturais e naturais, conforme previsto no primeiro artigo da Convenção de 1972. A paisagem cultural seria considerada uma tipologia do patrimônio cultural e se subdividiria em três categorias distintas, a saber: 1. a paisagem claramente definida: aquela intencionalmente criada pelo homem; 2. a paisagem organicamente em evolução: resultante de uma exigência humana, mas, que ao longo do tempo associou-se ao seu ambiente 
natural (essa categoria ainda se subdivide em outras duas: paisagem relíquia e paisagem contínua); 3 . a paisagem cultural associativa: caracterizada pela associação entre elementos naturais e fenômenos religiosos, artísticos ou culturais (Unesco, 1994, p. 14-15).

Com essa produção conceitual, o Comitê do Patrimônio Mundial criou a possibilidade de construir e/ou evidenciar e destacar da realidade concreta e objetiva, paisagens consideradas excepcionais. Tais paisagens culturais, por serem frutos de valores subjetivos de grupos sociais e de comunidades locais, mereceriam figurar como patrimônios mundiais. Do ponto de vista das políticas públicas, a produção conceitual do Comitê do Patrimônio Mundial, viria a possibilitar a instrumentalização de processos de patrimonialização de diferentes lugares do planeta. Entretanto, a criação do conceito de paisagem cultural revelaria também uma circunstância histórica muito mais complexa do que o estabelecimento de políticas públicas de patrimônio. À primeira vista, o que vem à tona, é o deslizamento de um conceito que tradicionalmente deu sustentação científica à geografia (Lowenthal, 2008) para o campo do Patrimônio Mundial. No entanto, as entrelinhas, deixam transparecer uma estratégia política e cultural de orientação em um mundo marcado por um complexo cenário geopolítico (Borttoloto, 2011).

Por um lado, parece haver poucas dúvidas quanto às origens do conceito de paisagem, uma vez que, os autores parecem concordar que este é fruto da efervescência cultural do período renascentista italiano e do florescimento e desenvolvimento das artes pictóricas nas regiões de Flandres e do Norte da Itália (Cosgrove, 1998). Por outro lado, estas também não se fazem ecoar quando o assunto é o conceito de paisagem cultural na geografia. Se levarmos em consideração a formação da geografia, enquanto ciência é, justamente, a concepção de paisagem elaborada por geógrafos alemães e franceses, entre o final do século XIX e o início do século $\mathrm{XX}$, que viria a permitir à disciplina ser encarada com seriedade no quadro das positividades do período. O conceito de paisagem elaborado pela geografia historicista como categoria de análise dentro dos cânones da objetividade positivista foi deslizando, desde sua origem na arte renascentista e flamenga até adquirir, no início do século XX, através do saber geográfico, uma dimensão histórica, cultural e subjetiva. Assim, a amplitude do conceito de paisagem está diretamente associada, não apenas ao florescimento de saberes oriundos do Renascimento, como também ao nascimento do saber geográfico, enquanto uma das positividades do final dos oitocentos.

Desde a aurora da geografia, enquanto saber científico, o conceito de paisagem foi operado, por um lado, como categoria de análise da realidade objetiva, fruto da observação e descrição de um determinado lugar. Por outro lado, a paisagem também foi encarada como representação de uma realidade objetiva. Assim, na geografia, o conceito de paisagem possibilitava não apenas a análise da realidade objetiva, posto que, esta é o resultado da transformação dos lugares pela história dos diferentes grupos humanos, como também, a paisagem era representada pelos diferentes modos de expressão humanos.

$\mathrm{O}$ ponto de inflexão sobre o conceito de paisagem seria, em meados do século XVIII, com a obra de Kant. As críticas do filósofo alemão, que durante 48 semestres deu aulas de geografia, viriam a pavimentar o caminho não apenas para a geografia clássica, como para todo o pensamento científico moderno, ao definir que "a coisa em si" e a sua representação existiam simultaneamente. Tal proposição, que tem a propriedade de fundar a epistemologia moderna e, com esta, o moderno pensamento científico, viria a ter grandes repercussões para a ciência como um todo, uma vez que, para Kant, o objeto não se reduzia à "coisa em si”, mas "à coisa" e sua representação (Capel, 1983, p. 317-319). Para a geografia, especificamente, a importância do pensamento kantiano não haveria de ser menor. O objeto da geografia, ou seja, a realidade objetiva deveria ser encarada como a realidade em si e a representação da realidade. O objeto da geografia era, portanto, o resultado concreto da ocupação histórica e cultural humana de uma parcela do espaço terrestre, mas era também a representação dessa parcela do espaço.

Considerar como paisagem o resultado da ocupação humana sobre o ambiente permitiu que o conceito de paisagem servisse como âncora para a geografia enquanto uma positividade científica, uma vez que, esta seria a partir de então, seu objeto de estudo. Fazer geografia, portanto, era compreender como a ação de uma determinada sociedade transformava o ambiente ao redor de acordo com as ferramentas à disposição e do seu uso através do equipamento cultural. A análise das paisagens não poderia prescindir de uma abordagem historicista. Compreender uma paisagem, no presente, implicava em investigar as origens e a evolução da ocupação humana daquele lugar em uma perspectiva evolutiva 
do passado até o presente. $\mathrm{O}$ mesmo processo teria o condão de ampliar e tornar mais complexo o conceito de paisagem, pois sendo objeto do conhecimento histórico, a paisagem também se apresentaria como uma construção narrativa. Portanto, se não era possível uma paisagem concreta sem um observador, tampouco seria possível uma paisagem sem narrador.

Desse modo, sendo a paisagem uma realidade objetiva, mas também um recorte conceitual da realidade e, ao mesmo tempo, um objeto cultural, não é difícil compreender o uso e a operacionalização do conceito pelo Comitê do Patrimônio Mundial. Dentro dessa perspectiva, a paisagem cultural não se restringe à excepcionalidade dos processos de ocupação, mas, comporta uma dimensão identitária, fortemente ligada à memória e à narrativa (Schama, 1996). Uma vez que o uso da memória e as construções narrativas sobre a paisagem são, ao fim e ao cabo, o resultado dos processos de apropriação do território por um determinado grupo social, a paisagem pode ser reconhecida como um patrimônio cultural (Braudel, 2011).

Em outras palavras, a paisagem é um dos fundamentos da noção de pertencimento e dos ideais de territorialidade, uma vez que, se apresenta como uma das balizas da realidade espaço-temporal, baliza sem a qual é impossível a construção de uma identidade completa (Meneses, 1999). Não é, portanto, de se estranhar que justamente esse conceito de paisagem cultural que sustentou a geografia clássica venha orientar o Comitê do Patrimônio Mundial da UNESCO em sua política de valorização dos grupos sociais e visibilidade das diferentes identidades. Tudo leva a crer, portanto, que a interpretação do conceito de paisagem construído pela geografia clássica do final do século XIX e início do século XX, foi fundamental na definição dos critérios do Patrimônio Mundial estabelecidos pela Convenção de 1972.

\section{A paisagem como patrimônio}

Como já dito na epígrafe do artigo, Ulpiano Bezerra de Meneses (Meneses, 1999, p. 59) escreveu que, a paisagem deveria ser vista como um bem indispensável ao equilíbrio da vida, uma vez que, esta responderia aos imperativos de territorialidade e de pertença de diferentes grupos humanos. Para o autor, portanto, a paisagem tem um eixo temporal capaz de situar historicamente uma miríade de grupos humanos que habitam ou habitavam o espaço terrestre e, dentro dessa perspectiva, a paisagem é fundamental em virtude da necessidade de inserção das trajetórias biográficas no espaço.

A julgar pela Convenção de 1972 e mais especificamente, pelo Operational Guidelines, que traz as orientações para a sua implementação, parece que o Comitê do Patrimônio Mundial privilegiou precisamente, os valores subjetivos dos grupos sociais na produção da paisagem. À medida que, a paisagem concentra os vestígios dos diferentes processos de ocupação humana ou, dos distintos momentos da ocupação de um determinado lugar, a Convenção se baseou no conceito de paisagem para construir uma tipologia capaz de enquadrar as diferentes dimensões da paisagem. A paisagem é cultural e histórica e, foi exatamente por esse motivo, que o Comitê do Patrimônio Mundial utilizou esse conceito como uma tipologia para os processos de patrimonialização.

Para o Comitê do Patrimônio Mundial, o processo de ocupação histórica ganhou relevância e singularidade, uma vez que o resultado da inscrição dos valores subjetivos de um determinado grupo social sobre um ambiente natural. Tendo em vista as dimensões espacial e temporal implicadas na moderna versão do conceito de paisagem, fica evidenciada a sua utilização no campo do patrimônio cultural. $\mathrm{Na}$ paisagem podem ser encontrados os vestígios da existência humana em diferentes tempos históricos e as marcas que tal existência imprime do espaço (Lowenthal, 2008). Entretanto, essa paisagem, bem como seus significados e atributos, serão sempre recortes narrativos feitos a partir de determinadas perspectivas. Em outras palavras, a paisagem cultural é um recorte espacial e temporal feito no espaço, ao qual podem ser atribuídos valores, para que, em última instância, ela seja reconhecida como um patrimônio cultural.

Nessa perspectiva, apresentaremos, a seguir, as narrativas dos dossiês de candidatura de dois bens culturais brasileiros, reconhecidos como Patrimônios Mundiais pela UNESCO, na tipologia de paisagem cultural. A primeira paisagem cultural brasileira em questão é a da cidade do Rio de Janeiro, incluída na Lista do Patrimônio Mundial em 2012. Em um evento eminentemente simbólico, mas com forte acento político, cultural e econômico, o Comitê do Patrimônio Mundial da UNESCO, em reunião em São Petersburgo, na Rússia, em 01 de julho de 2012, incluiria a cidade do Rio de Janeiro na Lista de Patrimônio Mundial, na categoria de paisagem cultural. Tal título seria concedido exatamente 40 anos após a reunião da UNESCO, 
em Estocolmo, Suécia, quando foi criado o Comitê do Patrimônio Mundial, com vistas para a proteção do Patrimônio Mundial e, vinte anos após a tipologia paisagem cultural ser criada na reunião de Santa Fé, no Novo México. A cidade do Rio de Janeiro seria a primeira área urbana do mundo considerada Patrimônio Mundial, dentro da tipologia paisagem cultural.

A segunda paisagem cultural brasileira reconhecida pela UNESCO como Patrimônio Mundial foi a da região da Pampulha, em Belo Horizonte, capital de Minas Gerais. O chamado "Conjunto Moderno da Pampulha", no qual se destaca a arquitetura modernista de Oscar Niemeyer, foi incluído na Lista da UNESCO durante a $40^{\mathrm{a}}$ reunião do Comitê do Patrimônio Mundial, ocorrida em Istambul, na Turquia, em julho de 2016. Incluído na Lista Indicativa do Brasil ao Patrimônio Mundial ainda na década de 1990, o conjunto da Pampulha teve sua candidatura lançada pelo governo brasileiro em 2015 e obteve o título de Patrimônio Mundial no ano seguinte. Naquela mesma reunião foram reconhecidos dezessete edifícios modernistas, localizados em diferentes países, os quais foram projetados pelo arquiteto franco-suíço Le Corbusier. Naquele contexto de evidente proeminência da arquitetura modernista no âmbito do Comitê do Patrimônio Mundial, o exemplo do conjunto da Pampulha se destacou como uma inscrição na tipologia de paisagem cultural do movimento moderno, embora a candidatura inicial tenha sido feita como "conjunto arquitetônico", como detalharemos a seguir.

A justificativa para a inclusão dessas paisagens culturais na Lista do Patrimônio Mundial está dentro de um amplo espectro de categorizações sobre o conceito de paisagem. A seguir analisaremos que elementos desse conceito, memórias e valores foram mobilizados nas elaborações das narrativas de consagração dessas paisagens brasileiras.

\section{Uma paisagem semeada "entre o mar e a montanha"}

A primazia da vida rural combina com o espirito da dominação portuguesa, que cuidou mais em fazer uma riqueza fácil do que planejar. A babitacão em cidades associa-se a manifestacões do espirito e da vontade. A construção de cidades foi um eficiente instrumento de dominacão ao ser, no mundo helenistico, por exemplo, o meio pelo qual foram criados órgãos locais de poder, segundo Max Weber. [...] O traçado dos centros urbanos na
América Espanbola denuncia o esforço de vencer retificar a paisagem. [...] Pouco importa aos nossos colonizadores a disciplina, se não forpara servir aos seus interesses imediatos. A forma em que nossas cidades se dispunham, comparadas às da América Espanhola, é um reflexo disso. A cidade que os portugueses construiram na América não contradiz o quadro da natureza, sua silbueta se enlaca na linha da paisagem. Nenbum rigor, nenhum método. O principio que norteon a atividade colonizadora dos portugueses foi a rotina, não a razão abstrata. A ordem que aceitam é a do semeador, desleixada e livre, não a do ladrilhador, feita com o trabalho dos homens.(Holanda, 1995, p. 61)

Certamente, o conceito de paisagem cultural adotado pelo Comitê do Patrimônio Mundial não estava sendo mobilizado como categoria de análise por Sérgio Buarque de Holanda (Holanda, 1995, p. 61), ao se referir à atividade colonizadora portuguesa no Brasil, no livro Raízes do Brasil, publicado em 1936. Todavia, ao afirmar que as cidades portuguesas na América não contradiziam o quadro da natureza e que a silhueta destas se enlaçava na linha da paisagem, Sérgio Buarque de Holanda, antecipava o olhar sobre a singularidade do urbanismo português na América.

A interpretação de Sérgio Buarque tem sido vista, como uma crítica ao urbanismo de traço lusitano, ou quem sabe a ausência deste, por historiadores do urbanismo. Contudo, a referência ao autor não ocorre a propósito de uma discussão sobre urbanismo, antes pelo fato de Sérgio Buarque, construir um tipo ideal que, de certa maneira, dialoga com o conceito, eminentemente geográfico, de paisagem cultural. $\mathrm{O}$ conceito de paisagem comporta uma organicidade que é característica da ocupação histórica dos lugares e, este, não tem necessariamente, a ver com planejamento. A reflexão de Sérgio Buarque mostra como o conceito de paisagem cultural, definido por geógrafos como Carl Sauer, Vidal de la Blache e, mais recentemete, Jean-Marc Besse, além de historiadores como David Lowenthal, Fernand Braudel, era conhecido pelo pensamento social brasileiro desde os anos de 1930. O tipo ideal do "semeador" construído por Sérgio Buarque em Raíres do Brasil dialoga com o conceito de paisagem cultural, definido como a escrita de uma determinada cultura sobre a TerraOs argumentos de Sérgio Buarque garantem a historicidade e a densidade da paisagem, na medida em que ele se refere às cidades portuguesas na América como uma espécie de modelo singular de adaptação e apropriação do quadro da natureza. Sérgio Buarque 
interpreta a ocupação do território brasileiro por uma população adventícia levando em consideração o desenho do traçado urbano e a morfologia das cidades como o resultado de um determinado traço cultural. Para o autor, a paisagem cultural urbana não se restringia à simples ocupação, ela era o resultado da apropriação da natureza por um determinado imaginário social.

Uma perspectiva semelhante pode ser encontrada no dossiê de candidatura que o Estado Brasileiro submeteu ao Comitê do Patrimônio Mundial, em 2011, pleiteando para uma determinada paisagem da cidade do Rio de Janeiro o título de Patrimônio Mundial. O bem cultural recebeu a denominação "Rio de Janeiro: Paisagens Cariocas entre a Montanha e o Mar", indicando a priori a tipologia do patrimônio cultural sob a qual estava sendo lançada a candidatura. De acordo com o dossiê, "o homem carioca demonstrou sua capacidade de adaptação do modelo português aos trópicos" e a cidade teria se desenvolvido a partir do aterramento de brejos, lagoas e mar, além da retirada de morros. Ainda segundo o dossiê,

Acompanhar a construcão da paisagem do Rio de Janeiro significa compreender suas etapas como um território em permanente relação com seus contornos internos e externos e seus elementos estruturadores ao longo do tempo: a cidade e a defesa externa, a cidade produtiva e a arricultura, a sua relacão social com os jardins, as florestas e o mar. (Iphan, 2012, p. 21).

Segundo o dossiê, o sítio alvo da chancela é subdividido em três setores, $\mathrm{A}, \mathrm{B}$ e $\mathrm{C}$, sendo o primeiro formado pelo Parque Nacional da Tijuca e pelo Jardim Botânico, o segundo pelo Parque do Flamengo, pela Entrada da Baía de Guanabara e pela Praia de Copacabana e pontões e o terceiro setor constituído pela área urbana na cidade e tomado no dossiê como zona de amortecimento ou buffer zone, segundo nomenclatura da UNESCOi. O Setor A foi intitulado "A Montanha, a Floresta e o Jardim" e abrange toda a área especificada no plano de manejo do Parque da Tijuca, além da área de entorno do Jardim Botânico (Iphan, 2012, p. 56). O Setor B intitula-se "A Entrada da Baía de Guanabara e as Bordas D'água" e compreende o Parque do Flamengo mais a Área de Proteção Paisagística dos Fortes, na entrada da Baía de Guanabara e orla de Copacabana, com pontões rochosos (Morro do Leme, Forte de Copacabana e Ponta do Arpoador) (Iphan, 2012, p. 59). O Setor C, intitulado "A
Paisagem Urbana" é "delimitado pelos ângulos visuais que partem dos dois principais picos contidos nos elementos do sítio: o do Corcovado e do Morro do Pico, em Niterói”'. Engloba os morros da Babilônia, São João, Catacumba, Cabritos, Saudade, que delimitam os bairros de Copacabana, Botafogo e Lagoa, o Morro da Viúva no Flamengo, o vale do Cosme Velho e Laranjeiras e a encosta sul do Morro de Santa Teresa até encontrar a borda do Parque do Flamengo, no centro da cidade (Iphan, 2012, p. 62).

Como mencionamos anteriormente, a tipologia paisagem cultural se subdivide em três categorias. Na candidatura, a paisagem do Rio de Janeiro foi apresentada como representativa de todas as categorias de paisagens propostas pela UNESCO. Assim, o Jardim Botânico, o Passeio Público, o Parque do Flamengo e a Orla da Praia de Copacabana foram considerados exemplos de paisagens desenhadas intencionalmente. O Parque da Tijuca e suas florestas replantadas no século XIX e regeneradas ao longo do tempo foram considerados um exemplo de paisagem contínua, organicamente em evolução. E o Corcovado somado ao Cristo Redentor, bem como o Pão de Açúcar com seu bondinho (teleférico) foram considerados exemplos de paisagens associativas, ou seja, aquelas que apresentam elementos naturais e culturais e cujas imagens projetam a cultura do Rio de Janeiro e do Brasil para o mundo.

Segundo determinação da Convenção de 1972 para serem incluídos na Lista do Patrimônio Mundial, os bens culturais, naturais ou mistos devem comprovar que possuem Valor Universal Excepcional (VUE), o qual se expressa objetivamente por meio da adequação das candidaturas aos critérios designados pela UNESCO, por meio do Operational Guidelines for the Implementation of the World Heritage (1994). Este documento, que é regularmente revisado pelo Comitê do Patrimônio Mundial, tem o objetivo de oferecer diretrizes aos Estados-Membros de maneira que sejam observados, adequadamente, os termos da Convenção. No caso específico do patrimônio cultural, tratam-se dos seis primeiros entre os dez critérios elencados pelo Comitê do Patrimônio Mundial. No caso da candidatura das "Paisagens Cariocas" a Declaração de VUE fundamentou-se na ideia de uma metrópole tropical que cresceu entre o mar, a montanha e a floresta, obtendo dessa forma, uma paisagem única e excepcional. A narrativa destaca o uso científico de elementos da natureza local, desde o período colonial. Também é mencionada a presença de 
paisagens desenhadas pelo homem, com destaque para a atuação de arquitetos, urbanistas e paisagistas modernistas, como Lucio Costa, Oscar Niemeyer e Roberto Burle Marx, os quais teriam agido diretamente na conformação da paisagem urbana do Rio de Janeiro, na segunda metade do século XX. E, finalmente, são frisadas as imagens constantes dessa paisagem, as quais são refletidas para o mundo, com toda a sua carga simbólica.

A candidatura "Rio de Janeiro: paisagens cariocas entre a montanha e o mar" foi submetida nos critérios (i) - representar uma obra prima do gênio criativo humano, devido às obras de Niemeyer, Reidy, Burle Marx e Lucio Costa; (ii) ser a manifestação de intercâmbio considerável de valores humanos durante um determinado período [...], por ser uma cidade latino-americana, de colonização portuguesa, com uma complexa paisagem cultural formada por inúmeras trocas de diferentes culturas, além de possuir um sítio natural original; (vi) - estar associado [...] a acontecimentos ou tradições vivas, com ideias ou crenças, ou com obras artísticas ou literárias de significado universal excepcional, por ser a cidade do Rio de Janeiro considerada a principal referência do imaginário social brasileiro e por ter sido ela capital do Brasil.

No que diz respeito aos critérios de autenticidade e integridade também exigidos pelo Comitê do Patrimônio Mundial a todas as candidaturas são mencionados a manutenção dos usos, das funções, formas, significados, concepções e localidades dos elementos que compõem a paisagem a ser reconhecida, como atestados de sua autenticidade. A permanência dos usos públicos, os materiais estruturais, as estéticas visuais e os significados garantem a integridade do bem, de acordo com a narrativa do dossiê. Ainda segundo o documento, a área a ser reconhecida e, consequentemente, protegida, englobaria os principais elementos que estruturam a paisagem cultural da cidade do Rio de Janeiro. Evidentemente, essa afirmação, bem como todo o recorte temporal e geográfico feito para que o bem cultural fosse definido e valorado, são passíveis de inúmeros questionamentos.

A cidade do Rio de Janeiro obteve o título de Patrimônio Mundial, na tipologia de paisagem cultural. Esse fenômeno social poderia ser visto como uma espécie de resistência de populações locais diante de uma explosão de investimentos externos e projetos de modernização que se espalhavam pelo mundo a partir da segunda metade do século XX. Visto por este prisma, a preservação do patrimônio histórico e cultural representa uma barreira aos interesses do lucro e, ao mesmo tempo, uma luta pela preservação da cultura e da identidade locais. No entanto, as políticas de preservação do patrimônio histórico e cultural, elaboradas por órgãos governamentais e especialistas em políticas públicas, adotaram a postura de preservar aquilo que é considerado patrimônio histórico e cultural, sem levar em consideração os diferentes segmentos da população.

Figura 3 - Paisagem cultural do Rio de Janeiro - Brasil.

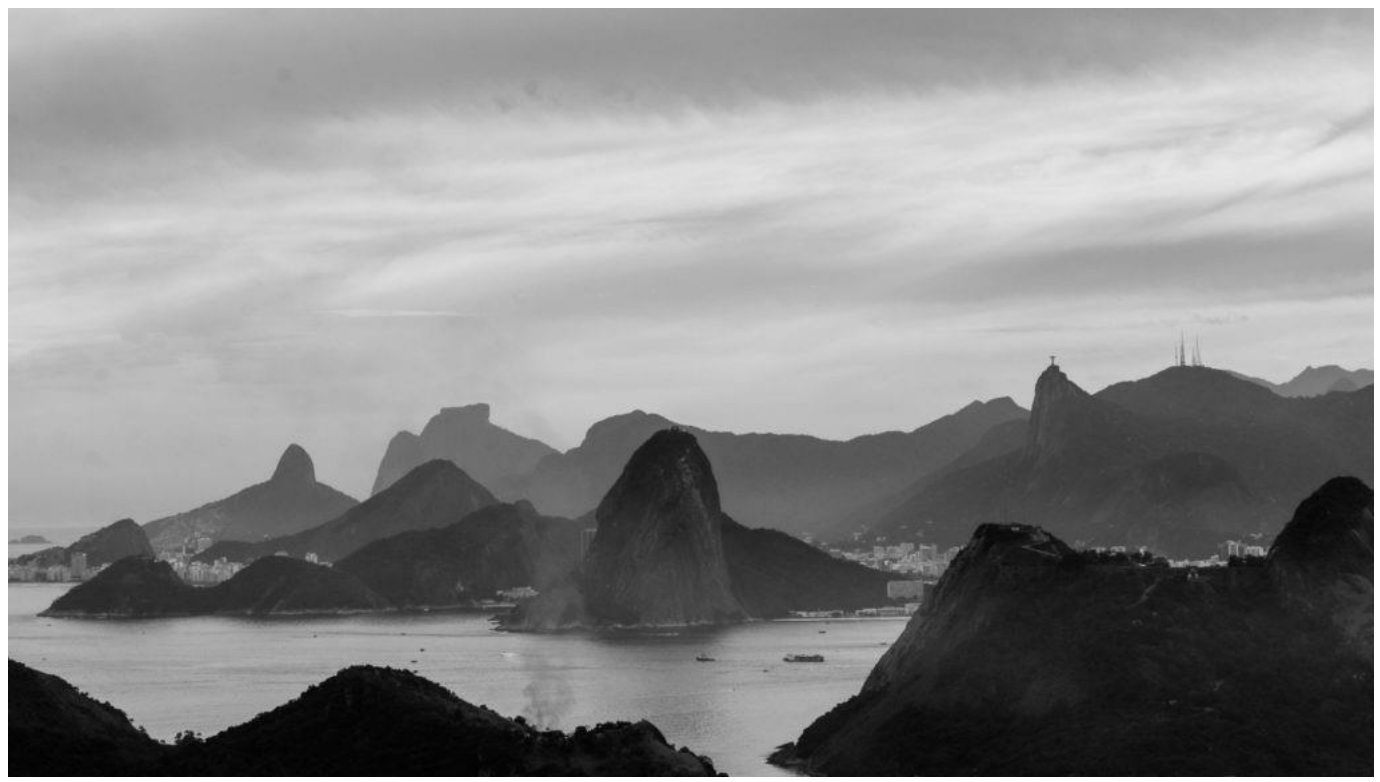

Fonte: WikiCommons/Karla F. Paiva. Cf: https://nacoesunidas.org/rio-de-janeiro-e-1a-paisagem-culturalurbana-declarada-patrimonio-mundial-da-unesco/. Última consulta em 19 de julho de 2020. 
Tal movimento, ainda que guarde um aspecto positivo, tem provocado, quase que invariavelmente, a cristalização da memória de determinados segmentos das populações. Iluminase, assim, uma memória específica, ao mesmo tempo, que se condena às trevas a memória de segmentos inteiros de uma mesma população. $\mathrm{O}$ modelo de preservação tem o efeito de proteger a memória cristalizada de parte dos projetos de modernização, portanto, de uma pequena parcela da população em detrimento da grande maioria que, lenta e silenciosamente, desaparece da memória sem deixar vestígios concretos. O problema é que o momento de implantação desses projetos, no passado, representou também o esquecimento ou a readequação de várias formas de ser e estar no mundo. Esse é o paradigma positivista que se ancora na afirmação de influências e cópias de ideias adventícias quando se debruça sobre os projetos de modernização na cidade do Rio de Janeiro. O mesmo movimento que, inevitavelmente, torna superficial a complexa circulação de ideias no período, bem como, subalterniza os conflitos existentes entre as diversas racionalidades.

A implantação de padrões de modernização e urbanização levou em consideração o desejo de um grupo de intelectuais que compreendia a modernidade como profissão de fé e as alternativas de planejamento propostas pelo poder público. Diante dessa circunstância, a população foi obrigada a se utilizar da criatividade para reinventar a vida cotidiana e recriar novas maneiras de ser e viver no espaço urbano. Pois, se urbanizar e modernizar foram modos de impor uma hierarquia de decisão e assegurar a organização e utilização do espaço, as práticas cotidianas nele exercidas são maneiras de reinventar esse mesmo espaço (Certeau, 1994, p. 25). Orquestrado pelo poder público e por interesses privados, tal processo agiu diretamente sobre a paisagem da cidade, optando por garantir um tipo de representação que se revela como um belo cenário, mas que, por hora, ainda esconde o verdadeiro sentido. Este sim, fruto da reinvenção do cotidiano pela população presente, portador da força simbólica do pertencimento.

Dentro desta perspectiva, o espaço urbano pode ser visto como um complexo sistema de significação que se exprime através dos elementos simbólicos e longe de ser ingênuo, evoca um modelo de civilização e um sistema de valores. Em outras palavras, o processo de patrimonialização foi um passo fundamental no sentido de privilegiar a singularidade da ocupação, mas ainda se espera que esta abra espaço para dar visibilidade às memórias encobertas. Dentro dessa perspectiva, o espaço urbano do Rio de Janeiro pode e deve ser analisado como um inventário das diferenças. Os projetos de modernização e urbanização não podem se reduzir ao triunfo da razão e da ideia de progresso de uma determinada classe. Tal perspectiva não permite compreender a miríade de experiências humanas inscritas no espaço urbano e torná-las visíveis enquanto história e acessíveis enquanto memória. Os projetos de modernização e urbanização devem ser compreendidos não como feitos heroicos da razão e do progresso, mas como a discussão de ideias e práticas, cujo resultado é uma nova ordem discursiva que inclui vencedores e perdedores.

O título de Patrimônio Mundial na tipologia de paisagem cultural é extremamente bem-vindo, sobretudo, porque revela um esforço sincero, por parte dos órgãos patrimoniais, na ampliação de categorias de análise, bem como, atualiza a questão central que é a discussão entre o universalismo dos cânones vigentes e os localismos que emergem das diferentes circunstâncias históricas e geográficas. Entretanto, urge a necessidade de se considerar como paisagem cultural aquelas áreas excluídas e subalternizadas que, se por um lado, não se incluem dentro de padrões estéticos ainda etnocêntricos, por outros representam os valores intangíveis da cidade.

\section{As curvas de um belo horizonte}

Em sua $40^{a}$ reunião ocorrida em 2016, o Comitê do Patrimônio Mundial recebeu três robustas candidaturas de bens culturais representativos do movimento moderno do século XX. Os EUA lançaram a candidatura de um conjunto representativo da obra do arquiteto Frank Lloyd Wright, Argentina, Bélgica, França, Alemanha, Índia, Japão e Suíça submeteram uma proposta conjunta referente à obra do arquiteto franco-suíço Le Corbusier e o Brasil submeteu a candidatura do "Conjunto Moderno da Pampulha", arquitetado por Oscar Niemeyer na década de 1940. Dessas três propostas, foram sugeridas mudanças no dossiê norte-americano, incentivando nova submissão e foram incluídas na Lista do Patrimônio Mundial as outras duas. Em uma reunião na qual tanta ênfase foi dada à arquitetura moderna, a candidatura brasileira se destacaria não apenas por representar a modernidade periférica do século XX, como também por ser a primeira inscrição de arquitetura moderna na tipologia paisagem cultural realizada pela UNESCO. 
Aquela não era a primeira vez que os edifícios projetados por Oscar Niemeyer e construídos em Belo Horizonte durante o governo do prefeito Juscelino Kubitschek, na década de 1940, seria tomado em conjunto, enquanto patrimônio cultural. No Brasil, a igreja de São Francisco de Assis, localizada na Pampulha, foi o primeiro exemplar de arquitetura modernista tombado pelo Instituto do Patrimônio Histórico e Artístico Nacional (Iphan) ainda em 1947, quatro anos após sua inauguração. E, embora esse tombamento isolado seja um marco na trajetória da proteção de bens culturais no país, tendo em vista ser seminal do ponto de vista da patrimonialização de exemplares da arquitetura moderna brasileira, seria como conjunto que a obra da Pampulha se consagraria. Assim, entre as décadas de 1980 e 2000, o conjunto da Pampulha receberia tombamentos estadual, federal e municipal, consagrando-se como um dos mais importantes trabalhos realizados por Oscar Niemeyer no país.

O "Conjunto Moderno da Pampulha", como foi nomeado no dossiê de candidatura ao título de Patrimônio Mundial, foi incluído na Lista Indicativa do Brasil ao Patrimônio Mundial em 1996. Em 2014 o governo brasileiro lançou oficialmente a candidatura do conjunto edificado por Niemeyer na categoria de bens culturais, mas, em 2015 o parecer do ICOMOS órgão que presta assessoria ao Comitê do Patrimônio Mundial da UNESCO nos casos das candidaturas de bens culturais - embora tenha expressado a aceitação da candidatura, fez algumas ressalvas. Entre as mudanças recomendadas pelo ICOMOS à candidatura do conjunto da Pampulha, destacamos a sugestão de que essa fosse feita na tipologia paisagem cultural. Em outras palavras, o ICOMOS sugeria uma reorientação do olhar do Brasil sobre a obra de Oscar Niemeyer erguida na Pampulha, considerando-a parte de uma realidade mais abrangente que poderia ser reconhecida como Patrimônio Mundial. Tratava-se de tirar o foco dos edifícios modernistas, tão somente, e de ampliar a mirada sobre aquela região da cidade de Belo Horizonte, considerando o entorno daqueles edifícios e as relações entre atividades sociais e meio natural presentes naquela paisagem.

De acordo com a versão final do dossiê, o "Conjunto Moderno da Pampulha" tal como foi reconhecido pela UNESCO em 2016, é formado pelos edifícios e jardins do antigo Cassino, hoje Museu de Arte da Pampulha, da Casa do Baile, que se transformou em Centro de Referência em Urbanismo, Arquitetura e Design, da igreja de São Francisco de Assis, do Iate Golfe Clube, atual Iate Tênis Clube e da antiga residência de Juscelino Kubitscheck, atual Casa Kubitscheck, além do espelho d'água e da parte da orla da Lagoa da Pampulha, onde os edifícios se encontram. O lago foi descrito como elemento articulador da unidade do conjunto, explicitando a interação ser humano natureza, foco da tipologia de paisagem cultural tal como proposta pela UNESCO.

Figura 4 - "Conjunto Moderno da Pampulha", Belo Horizonte, MG - Brasil.

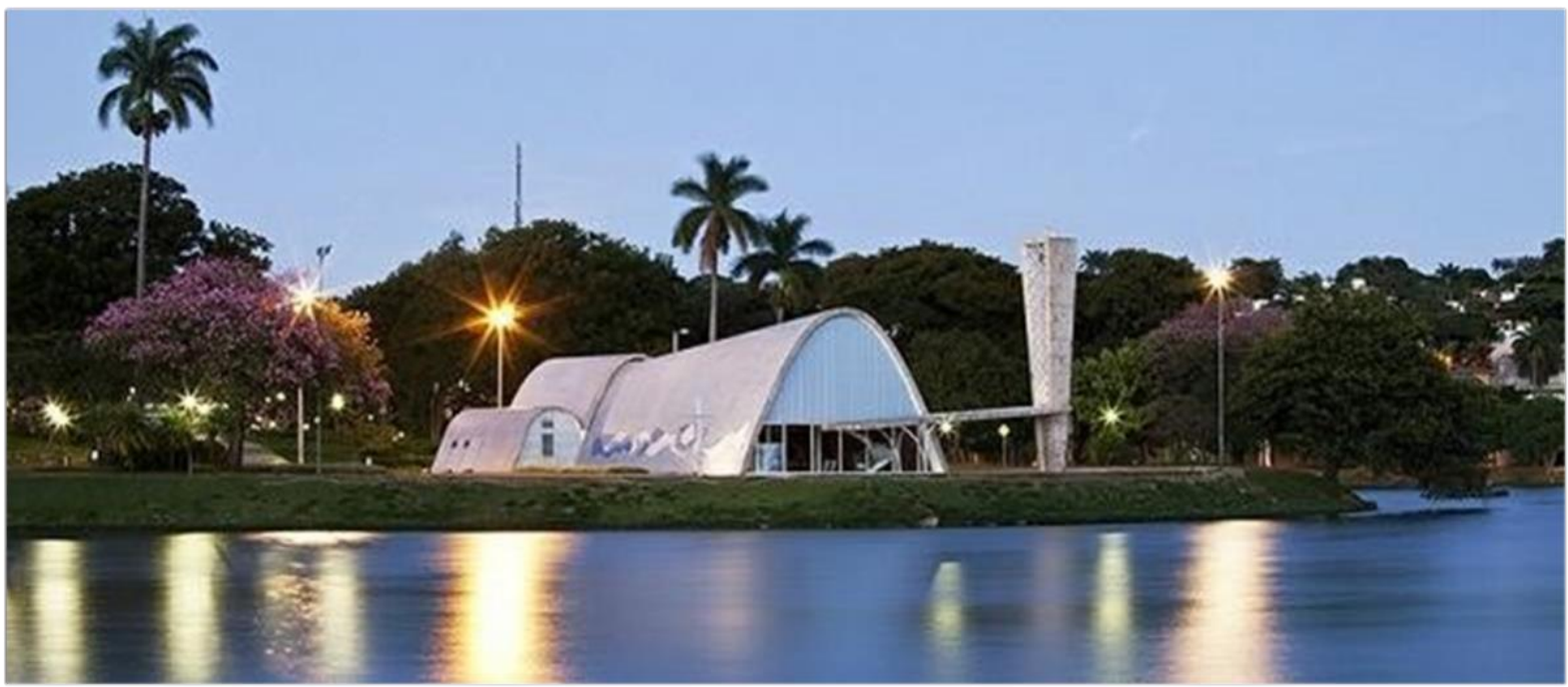

Fonte: Site acritica.net (Divulgação). Detalhe: Igreja de São Francisco de Assis

Cf: http://www.acritica.net/editorias/cultura/conjunto-arquitetonico-de-bh-pode-virar-patrimoniomundial/170236/. Última consulta em 19 de julho de 2020. 
O VUE do "Conjunto Moderno da Pampulha" foi ancorado nos critérios (i) representar uma obra-prima do gênio criativo humano; (ii) - exibir um evidente intercâmbio de valores humanos, ao longo do tempo ou dentro de uma área cultural do mundo, que teve impacto sobre o desenvolvimento da arquitetura ou da tecnologia, das artes monumentais, do urbanismo ou do paisagismo e (iv) - ser um exemplar excepcional de um tipo de edifício, conjunto arquitetônico ou tecnológico ou paisagem que ilustre um estágio significativo da história humana.

Observa-se que os critérios (ii) e (iv) fazem referência à paisagem, mas a narrativa de valoração do dossiê não enfatiza exatamente esse aspecto. Diferentemente do dossiê do "Rio paisagem cultural", o dossiê da Pampulha não explora as categorias da paisagem cultural também propostas pelo Comitê do Patrimônio Cultural para que o bem seja minuciosamente caracterizado. Não fica claro, portanto, a qual das três possibilidades - que citamos ao analisar o dossiê do Rio - o conjunto se adequaria. Nisso percebe-se claramente, como o processo de valoração de um bem é historicamente construído e, portanto, é fruto de uma elaboração intelectual. Percebe-se, também, como a paisagem é sempre um recorte espacial e temporal, e, da mesma forma, fruto de uma mirada, ou de uma narrativa.

O conjunto da Pampulha é apresentado como marco referencial da evolução da arquitetura mundial e obra de arte total, uma vez que contou com as participações de outros profissionais brasileiros como o pintor Cândido Portinari e o paisagista Roberto Burle Marx. Segundo o dossiê, o conjunto também é um exemplo de interação universal que resulta em apropriações particulares, no caso específico das práticas arquitetônicas do século XX. A influência de Le Corbusier, representante do movimento moderno internacional e a exploração da plasticidade do concreto armado, com uso de curvas, que seria a marca do modernismo de Oscar Niemeyer ilustrariam esse intercâmbio de ideias. Nesse momento, aliás, o paisagismo volta à cena, quando a narrativa frisa o dueto entre as curvas de Niemeyer e a paisagem e cultura brasileiras, incorporando ao funcionalismo puro uma "poética tropical". Também foi lembrada, a valorização de espécies vegetais locais no paisagismo de Burle Marx, como forma de valorizar a paisagem e a biodiversidade locais. E, por último, o conjunto da Pampulha foi narrado como um símbolo da independência política do Brasil, da criação da identidade nacional, da modernização do país, do empreendedorismo de
Juscelino Kubitschek, tendo sido responsável por uma "mudança nos rumos da arquitetura e do paisagismo modernos.

Tendo em vista tais justificativas, a minuta da Declaração de VUE afirma que o "Conjunto Moderno da Pampulha" constitui-se em um marco vivo, íntegro e autêntico da história da arquitetura mundial e da história brasileira e das Américas. Interessante observar que, diferentemente do dossiê do "Rio paisagem cultural", a excepcionalidade a ser reconhecida está ligada às obras arquitetônicas como obras de arte e ao seu valor histórico, mas, não a seu valor enquanto paisagem cultural. Os elementos narrativos que fazem menção à paisagem parecem servir de moldura àquilo que o dossiê de fato enfatiza, que é precisamente a arquitetura de Oscar Niemeyer.

No que diz respeito à autenticidade, o reconhecimento internacional do conjunto e as reiteradas menções a ele em reportagens e trabalhos acadêmicos, cumpririam o papel de atestá-la. Quanto à integridade, afirma-se que o conjunto está completo e intacto, mantém os mesmos materiais utilizados em sua construção, permanece com os mesmos usos, voltados ao lazer, cultura e esportes e, finalmente, os cinco elementos do grupo seriam interligados pelo espelho d'água, que cumpriria, assim, sua função integradora. A buffer zone no entorno do bem a ser protegido, foi dividida em seis subzonas abarcando a parte da lagoa distante dos prédios projetados por Niemeyer, os bairros São Luís, Bandeirantes, Braúnas, Jardim Atlântico e Garças, os estádios Mineirão e Mineirinho e o Centro Esportivo Universitário (CEU) da Universidade Federal de Minas Gerais (UFMG) e a Avenida Portugal.

O histórico da paisagem cultural do "Conjunto Moderno da Pampulha" apresentado no dossiê, está relacionado à Semana de Arte Moderna de 1922, à influência de Le Corbusier entre os arquitetos modernos da chamada "Escola Carioca" (entre eles Niemeyer), aos princípios da arquitetura moderna, aos trabalhos de Niemeyer, Portinari e Burle Marx. Além disso, estaria relacionado à modernização de Belo Horizonte por JK, com o processo de urbanização da região da Pampulha, com a retirada de fazendas e a construção de um conjunto moderno de incentivo ao lazer e ao turismo. De forma muito isolada, o texto menciona o fato de que a lagoa da Pampulha era artificial e havia sido construída na década de 1930 visando ao abastecimento de água daquela região de Belo Horizonte. $\mathrm{O}$ rio no qual foi realizada a barragem que gerou a lagoa sequer é citado. A esse respeito, 
menciona-se, apenas o fato de que a bacia hidrográfica de onde vem a água do lago artificial banha não apenas o município de Belo Horizonte, mas, também o de Contagem, na Região Metropolitana da capital mineira. Importante destacar que, a melhoria da qualidade da água da lagoa da Pampulha, bem como o plano de gestão da bacia hidrográfica que a mantém foram condicionantes impostas pelo ICOMOS, antes da concessão do título de Patrimônio Mundial.

Tudo isso chama a atenção se considerarmos que a candidatura estava sendo feita na tipologia de paisagem cultural (não inicialmente, mas, ao fim do processo, a candidatura foi efetivada nessa tipologia) e, paradoxalmente, a narrativa do dossiê ilumina os aspectos culturais do bem cultural e dá pouca importância aos aspectos naturais. A exceção seria o paisagismo de Burle Marx, que, aparece muito mais no sentido de endossar a ideia de uma "obra de arte total" do modernismo brasileiro, que para consubstanciar a ideia de uma paisagem cultural, embora evidentemente, cumpra também esse papel. No entanto, é esse o dossiê por meio do qual o chamado "Conjunto Moderno da Pampulha" foi inscrito na Lista do Patrimônio Mundial. Portanto, é a ele que nos voltamos nesse exercício de análise das narrativas para identificar o conceito de paisagem cultural que vem sendo operacionalizado pela UNESCO e, consequentemente, pelos órgãos brasileiros de preservação do patrimônio, que elaboram os dossiês. Para compreender esse "descompasso" entre a narrativa do dossiê e o resultado final que a partir dele, o Brasil logrou conquistar, cremos ser importante um detalhamento de parte do processo de candidatura da Pampulha. Por esse caminho, esperamos abordar a historicidade do processo e nela, o nosso objeto principal, que é o conceito de paisagem cultural.

O dossiê enviado pelo Brasil ao Comitê do Patrimônio Mundial propunha a candidatura do "Conjunto Moderno da Pampulha" como conjunto arquitetônico, ou seja, uma candidatura na categoria de Patrimônio Mundial. Os trabalhos de outros artistas tais como o paisagismo de Roberto Burle Marx, e as artes plásticas de Cândido Portinari e Alfredo Ceschiatti, agregariam ainda mais valor àquela obra que seria, portanto, reconhecida como "obra de arte total". O que ocorreu, no entanto, é que a avaliação realizada pelo ICOMOS (Documentos Unesco, 2016) no segundo semestre de 2015 (e publicada no ano seguinte) apresentou outra possível leitura daquele mesmo bem cultural. De acordo com o relatório, a arquitetura modernista de Oscar Niemeyer demonstrava adaptação da proposta do movimento modernista internacional às condições brasileiras. No caso específico da Pampulha, o documento ressalta o diálogo entre as curvas dos edifícos de Niemeyer e a Serra do Curral que circunda a cidade de Belo Horizonte. Além disso, o ICOMOS interpreta os edifícios projetados por Oscar Niemeyer como partes de uma composição maior, a qual envolveria o lago artificial e a região da cidade que o circunda. Para os técnicos do ICOMOS, o "conjunto" da Pampulha ganhava unidade não pelo fato de terem uma unidade de linguagem arquitetural ou por terem sido todos planejados por Oscar Niemeyer e por fazerem parte de um único projeto de urbanização daquela região de Belo Horizonte no governo do então prefeito Juscelino Kubitschek. Esses, seriam, sem dúvida, elementos importantes, mas, a essa narrativa de unidade do conjunto, somou-se outra, segundo a qual, a interação entre os edifícios era garantida pelo lago artificial sinuoso, em cujas águas as obras arquitetônicas são espelhadas e que traça um caminho entre elas. Além do lago, o paisagismo de Burle Marx também foi compreendido como elemento agregador fundamental, unindo os edifícios e compondo com eles e o lago uma paisagem intencionalmente elaborada e absoutamente dialógica em relação ao seu entorno. É precisamente essa composição que, segundo os técnicos do ICOMOS, teria um "valor universal excepcional".

Fica claro, portanto, que a interpretação que o ICOMOS fez do "Conjunto Moderno da Pampulha" é muito mais ampla que aquela intencionada pelo Brasil ao lançar a candidatura. $\mathrm{Na}$ interpretação dada pelo órgão internacional, os edifícios de Oscar Niemeyer, por suas características arquitetônicas, mas, também, por seu diálogo com o ambiente ao redor, seriam uma espécie de "produto moderno brasileiro", ou, em outras palavras, a criação de uma paisagem modernista gerada a partir da adaptação do modelo internacional às condições ambientais e culturais do Brasil. Daí derivaria sua raridade e sua excepcionalidade. O relatório do ICOMOS esclarece, ainda, que após a solicitação de algumas informações mais precisas e de um plano de gestão para o bem cultural em questão, o Brasil teria submetido, em fevereiro de 2016, um dossiê de candidatura "ligeiramente revisado". Foi este dossiê um pouco modificado após o parecer do ICOMOS, que foi considerado na reunião do Comitê do Patrimônio Mundial realizada em julho de 2016 e na qual o "Conjunto Moderno da Pampulha" foi incluído na Lista do Patrimônio Mundial. 
Embora nosso objetivo nesse artigo não seja uma análise do processo de candidatura - o que incluiria a análise de documentos produzidos pela UNESCO e do processo como um todo - mas, uma análise das narrativas de dois dossiês de candidaturas, no caso específico da Pampulha, é necessário explicar essa parte do processo, pelo fato de a intenção primeira do Brasil não ter sido a candidatura como paisagem cultural e sim, como conjunto arquitetônico. Contudo, como esclarece o parecer do ICOMOS, não foram necessárias grandes mudanças no dossiê, naquilo que dizia respeito à descrição do bem e ao seu "valor universal excepcional". As mudanças significativas solicitadas diziam respeito às restaurações que o órgão considerava necessárias e, principalmente, ao plano de gestão do bem, após o reconhecimento da UNESCO como Patrimônio Mundial. E isso torna a análise da narrativa do dossiê como caminho para compreender os usos do conceito de paisagem cultural pelo campo do patrimônio mundial, ainda mais interessante.

A Convenção de 1972 estipulou duas categorias de patrimônios: os "patrimônios culturais mundiais" e os "patrimônios naturais mundiais". Com o passar dos anos e com as mudanças operadas no campo do Patrimônio Mundial, outras categorias foram criadas, a partir de novas interpretações do texto da Convenção. Assim, viriam, por exemplo, o "patrimônio misto mundial", que é aquele que mescla elementos culturais e naturais e também o "patrimônio cultural imaterial da humanidade". Essas categorias, são no entanto, termos bastante genéricos e, por essa razão, cada uma delas engloba definições mais específicas dos bens, que são as chamadas tipologias do Patrimônio Mundial. Não trataremos aqui de todas, evidentemente, mas, dentre os bens que podem ser classificados como patrimônios culturais, incluem-se as paisagens.

A paisagem cultural é, portanto, uma tipologia do patrimônio cultural mundial, da mesma forma que os conjuntos arquitetônicos e, como tal, seu valor excepcional universal é demonstrado, digamos assim, a partir dos mesmos critérios que são aqueles seis elencados pelos Operational Guidelines, aos quais nos referimos anteriormente. Se no plano narrativo do dossiê as mudanças podem ser pequenas, o mesmo não ocorre com a prática, após o processo de inscrição do bem na Lista do Patrimônio Mundial. No caso de um conjunto arquitetônico o VUE a ser comprovado, bem como a proteção após a nomeação estarão centrados nas edificações em questão. No caso das paisagens culturais, conforme o entendimento do conceito, sobre o qual tratamos anteriormente, pode-se afirmar que o VUE e a proteção que adviria de uma possível nomeação, estariam focados não apenas na arquitetura de Niemeyer, mas, em todos os elementos constitutivos da paisagem destacada para a candidatura.

Disso decorre uma questão interessante que demonstra não apenas a subjetividade do processo de candidatura e de avaliação, como também, o fato de tais exercícios de valoração se ancorarem em elaborações narrativas histórica e geograficamente situadas. O mesmo dossiê no qual a equipe técnica do Brasil vislumbrava um conjunto arquitetônico e por meio do qual visava à sua consagração como um Patrimônio Mundial, foi "lido" - aqui não apenas no sentido prático, mas, também no metafórico - como uma narrativa de consagração de uma paisagem cultural da qual aquele conjunto fazia parte, mas que o extrapolava. Caberia aqui uma análise das razões pelas quais os técnicos do ICOMOS teriam preferido considerar como bem cultural, não apenas os edifícios de Oscar Niemeyer com suas respectivas obras de arte agregadas, mas a paisagem cultural da qual eles fariam parte. Nessa nova narrativa, o lago, o paisagismo de Burle Marx e os bairros no entorno ganham centralidade e o plano de gestão precisa ser muito mais amplo. Ao invés de se limitar à preservação dos edifícios, exige-se dos gestores que considerem a restauração do paisagismo, a limpeza da água do lago artificial e a qualidade de vida no entorno, pois, todos esses seriam considerados elementos constituintes do bem cultural reconhecido com Patrimônio Mundial.

Uma simples mudança de interpretação da narrativa de valoração do bem, traria tantas e tão profundas mudanças, que, certamente, aumentaram de maneira considerável, os compromissos e responsabilidades das diversas instâncias da adminsitração pública brasileira e dos próprios cidadãos na gestão daquele bem. A partir dessa constatação e do conhecimento do trabalho da UNESCO é possível inferir sobre as razões que levaram os técnicos do ICOMOS a fazerem uma leitura do "Conjunto Moderno da Pampulha" como uma paisagem cultural. Não o faremos, no entanto, nesse artigo, embora nossas pesquisas nesse sentido continuem e embora pretendamos fazê-lo em outros momentos. Para a análise que aqui propomos, o fundamental é que se compreenda que, uma vez que os critérios de valoração sejam os mesmos, porque se trata da mesma categoria de patrimônio, a narrativa do dossiê poderá não ser tão diferente se a tipologia foi conjunto arquitetônico ou paisagem cultural. 
O que muda fundamentalmente - e esse é ponto mais importante - é o olhar que se lança sobre o bem: pode ser uma mirada específica, que também pode ser considerada mais restrita; ou pode ser uma visão mais ampla, que considera os edifícios modernistas uma parte no todo, que é a paisagem cultural que eles ajudam a compor. Considerandose apenas o dossiê de candidatura, vemos um claro exercício de elaboração de narrativas por meio da qual se "cria" um bem cultural, bem como os valores que poderão torná-lo um Patrimônio Mundial.

É ainda, importante acrescentar que, de maneira semelhante ao que destacamos no caso do dossiê do Rio de Janeiro, no qual privilegiouse uma paisagem marcada pela visão de mundo de determinados grupos sociais impressa no espaço, em detrimento de outras visões que também compõem a cidade, no caso da Pampulha o recorte acabou por favorecer determinados grupos sociais também. Apenas a título de exemplo podemos mencionar os bairros pobres que fazem parte da região da Pampulha, incorporados como "zona de amortecimento", ou seja, como área de proteção ao patrimônio de VUE e não parte dele. A estátua em honra a Iemanjá, localizada às margens do lago da Pampulha, embora seja um local importante para grupos praticantes de religiões de matrizes africanas, também não é sublinhada pelo dossiê. Hoje ela está inserida na área reconhecida como Patrimônio Mundial, mas, a narrativa que a englobaria física e simbolicamente ao VUE do "Conjunto Moderno da Pampulha" constitui-se também num esquecimento provocado pelo dossiê.

Nesse segundo exemplo de paisagem cultural brasileira reconhecida pela UNESCO como Patrimônio Mundial, observa-se, portanto, os mesmos pontos que vimos frisando ao longo do artigo: o caráter subjetivo da paisagem cultural e do processo de atribuição de valor a um bem cultural. Sabemos que a elaboração de memórias sempre será um recorte e, portanto, se constituirá de lembranças e esquecimentos. No entanto, o esforço da UNESCO em utilizar um conceito mais amplo como a paisagem cultural, demonstra um passo em direção a visões igualmente mais abrangentes do patrimônio cultural de uma sociedade. O que fica evidente nas análises desses dois dossiês, no entanto, é uma reiteração de um olhar, de uma concepção de patrimônio que segue privilegiando determinados grupos sociais e visões de mundo em detrimento de outros.

\section{Conclusão}

O presente artigo resulta de dois trabalhos de investigação sobre as políticas públicas de patrimônio cultural em um momento de expansão de capitais e das forças produtivas em quase todo o espaço terrestre. A ideia era compreender porque, em um momento de reestruturação espacial das forças produtivas, a questão do patrimônio cultural acirrava os ânimos e exaltava significativa parcela das populações envolvidas. Constatou-se que as políticas de patrimônio cultural recorreram ao uso da memória e construíram narrativas identitárias para justificar a defesa do patrimônio cultural.

Os questionamentos levaram a uma investigação sobre as políticas de Patrimônio Mundial, conduzidas pelo Comitê do Patrimônio Mundial, em parceria com os Estados-membros no nosso caso, o Brasil - e relativas à paisagem cultural. Como vimos, o conceito da geografia passou a ser uma categoria de análise de bens culturais no campo do Patrimônio Mundial da UNESCO.

A ampliação da investigação revelou o uso do conceito de paisagem cultural, em suas diferentes categorias, como base conceitual para as políticas públicas de construção, preservação e conservação do patrimônio cultural no Brasil pelo âmbito do Comitê do Patrimônio Mundial. Com isso, o foco do trabalho voltou-se para a relação entre o conceito de paisagem cultural, em sua dimensão histórica e espacial e a ideia de patrimônio cultural do Comitê do Patrimônio Mundial e das demais instituições a ele relacionadas. Em outras palavras, o trabalho acabou se voltando para a maneira como o Comitê do Patrimônio Mundial organizou o seu mundo conceitual e operacionalizou o conceito de paisagem cultural no que diz respeito aos sítios brasileiros. As narrativas produzidas pelo Brasil precisaram atender ao entendimento daquele órgão e das instituições a ele ligadas sobre o que vem a ser paisagem cultural.

Isso ficou particularmente evidenciado no caso do "Conjunto Moderno da Pampulha", uma vez que a narrativa do dossiê elaborada para o reconhecimento de um conjunto arquitetônico foi reinterpretada pelos técnicos do ICOMOS e pelo Comitê do Patrimônio Mundial como uma narrativa de valoração de uma paisagem cultural. $\mathrm{Na}$ mesma narrativa, na qual as instituições e técnicos do Brasil visualizaram um conjunto arquitetônico, os organismos internacionais visualizaram uma paisagem cultural. Isso evidencia não apenas o que aqueles organismos entendem como paisagem cultural, como também que, embora na prática a 
gestão desse bem vá mudar consideravelmente, no plano narrativo haveria poucas diferenças entre um e outro. Bastava uma leitura que descentralizasse a arquitetura de Oscar Niemeyer, dando protagonismo a outros elementos, como o lago e o paisagismo e ampliando a visão tirando o foco apenas daquelas obras de arte, para pensá-las em todo os seu entorno.

A investigação conduziu, portanto, não apenas para o conceito de paisagem cultural operado pelo Comitê do Patrimônio Mundial, mas, sobretudo, para o seu sentido último que é abarcar os distintos modos de vida e as diferentes formas de ocupação do espaço. O conceito de paisagem e a tipologia dele derivada agrega a atuação dos poderes públicos no projeto civilizatório de cidades, mas, além disso, tem, em potencial, o condão de incorporar a ação histórica de populações inteiras que de maneira criativa foram inventando modos de vida. Os dois casos em questão, tanto a cidade do Rio de Janeiro como o "Conjunto Moderno da Pampulha" aparecem, então, como emblemáticos, no sentido de serem exemplos de paisagens culturais nos trópicos. Por outro lado, as narrativas de seus dossiês e os recortes espaciais definidos poderiam englobar física e simbolicamente outros elementos que, como vimos, foram negligenciados.

$\mathrm{O}$ artigo procurou mostrar, então, como o conceito de paisagem não se reduziu a um objeto de estudo, ou a uma perspectiva estética, ou tampouco, a uma categoria de análise, mas antes, se transformou em uma tipologia nas mãos do Comitê do Patrimônio Mundial. Entretanto, nos processos de pesquisa e análise das narrativas dos dossiês, observou-se que esse potencial já provocou mudanças físicas na concepção do patrimônio, mas, as mudanças simbólicas são muito menos expressivas. Em outras palavras, se os recortes espaciais e o número de elementos constitutivos de uma paisagem cultural brasileira declarada Patrimônio Mundial são muito mais amplos que candidaturas que considerassem apenas edifícios ou monumentos - individuais ou em conjunto - em termos da diversidade das ações históricas de diferentes grupos sobre o espaço, nossa representatividade ainda é muito restrita. As duas paisagens culturais brasileiras reconhecidas como Patrimônios Mundiais apresentam as transformações espaciais de grupos dominantes e relegam às ocupações de grupos subalternizados, um papel marginal em todo esse processo.

Contudo, cremos que essas duas iniciativas já foram passos importantes e que, a análise crítica que propomos pode contribuir para que, em novas experiências, o potencial da categoria de paisagem cultural possa ser ainda mais explorado pelo Brasil. A paisagem é essencial para as necessidades humanas, uma vez que, representa a relação fundamental da existência humana com o seu entorno, os ideais de pertencimento e territorialidade que, junto à dimensão temporal, compõem a identidade local. É, precisamente, essa riqueza de identidades locais, que caracteriza a cultura brasileira - e, em especial, aquela impressa no espaço - que acreditamos, possa ser sublinhada em nossas paisagens culturais a serem reconhecidas como excepcionais.

\section{Referências bibliográficas}

Besse, J-M. (2006). Ver a Terra: seis ensaios sobre a paisagem e a geografia. São Paulo: Perspectiva.

Besse, J-M. (2014). O Gosto do Mundo: exercícios de paisagem. Rio de Janeiro: EdUERJ.

Borttoloto, C. (2011). A salvaguarda do patrimônio cultural imaterial na implementação da Convenção da Unesco de 2003. Revista Memória em Rede, 2 (4), 7-17. Recuperado em 21 de julho de 2019, https://periodicos.ufpel.edu.br/ojs2/index.p hp/Memoria/article/view/9532.

Braudel, F. (2011). L' Identité de La France. Paris: Flammarion.

Capel, H. (1983). Filosofía y ciencia en la geografía contemporánea. Barcelona: Barcanova, S.A.

Certeau, M. (1994). A Invenção do Cotidiano. Petrópolis: Vozes.

Conseil de l'Europe. (2000). European Landscape Convention and reference documents. Recuperado em 21 de julho de 2020, https://rm.coe.int/CoERMPublicCommo nSearchServices/DisplayDCTMContent? documentId $=09000016802 \mathrm{f} 80 \mathrm{c} 6$.

Cosgrove, D. (1998). A geografia está em toda parte. Cultura e simbolismo nas paisagens humanas. In R. L. Correa \& Z. Rosendahl (Orgs.) (Ed.). Paisagem, Tempo e Cultura (pp. 92-123). Rio de Janeiro: EDUERJ.

Holanda, S. B. (1995). Raízes do Brasil. São Paulo: Cia. das Letras.

Iphan. (2012). Dossiê de candidatura do Rio de Janeiro: paisagens cariocas entre a montanba e o mar. Recuperado em 21 de julho de 2020, http://portal.iphan.gov.br/uploads/ckfin der/arquivos/Dossi $\%$ C3\%AA\%20portug 
u $\%$ C $3 \% \mathrm{AAs}^{2} \% 2028 \% 20 \mathrm{mar} \% \mathrm{C} 3 \% \mathrm{~A} 7 \mathrm{o} \% 2$ 02011\%20RJ.pdf.

Iphan. (2016). Dossiê de candidatura do Conjunto Moderno da Pampulha: candidato a Patrimônio Cultural da Humanidade. Recuperado em 21 de julho de 2020, http://portal.iphan.gov.br/uploads/ckfinder Larquivos/FMC dossie conjunto moderno \%20da pampulha.pdf.

Lowenthal, D. (2008). Passage du temps sur le paysage. Paris: Editeur INFOLIO.

Martin, O. \& Piatti, G. (Ed.). (2008). World Heritage and buffer zones. International Expert Meeting on World Heritage and buffer zones. Recuperado em 21 de julho de 2020, https://unesdoc.unesco.org/ark:/48223/pf0 000181966.

Meneses, U. (1999). A paisagem como fato cultural. In E., Yazigi (Ed.). Turismo e Paisagem (pp. 29-64). São Paulo: Contexto.

Ribeiro, R. W. (2007). Paisagem Cultural e patrimônio [Versão eletrônica]. Rio de Janeiro: IPHAN/COPEDOC. Recuperado em 21 de julho de 2020,

\section{Notas}

i Zonas de amortecimento ou buffer zones são áreas no entorno dos bens a serem preservados e que têm a função principal de garantir a preservação do bem e de assegurar a manutenção de seu Valor Universal Excepcional. A esse respeito, conferir: (Martin \& Piatti, 2008). http://portal.iphan.gov.br/uploads/publicac ao/SerPesDoc1 PaisagemCultural m.pdf.

Schama, S. (1996). Paisagem e memória. São Paulo: Companhia das Letras.

Unesco. (1972). Convenção para a proteção do patrimônio mundial, cultural e natural. Recuperado em 21 de julho de 2020, https://whc.unesco.org/archive/convention -pt.pdf.

Unesco. (1994). Operational Guidelines for the Implementation of the World Heritage Convention. Recuperado em 21 de julho de 2020, https://whc.unesco.org/en/guidelines/.

Unesco. (2016). Évaluations des propositions d'inscription de biens mixtes et culturels sur la Liste $d u$ patrimoine mondial. Rapport de l'ICOMOS pour le Comité du patrimoine mondial - 40e session ordinaire, Istanbul, 10-20 juillet 2016, (pp. 97-112). Recuperado em 21 de julho de 2020, https://unesdoc.unesco.org/ark:/48223/pf0 000245912 fre?posInSet $=2 \& q u e r y I d=f 2 b 01$ c0e-334e-4917-8536-70813daee0b8.

ii É importante esclarecer que a inscrição de fato, deu-se apenas nos critérios $\mathrm{V}$ e VI, embora não pretendamos abordar os detalhes da tramitação do processo no âmbito deste artigo. Cf: site da UNESCO para maiores detalhes da inclusão do bem na Lista do Patrimônio Mundial: https://whc.unesco.org/en/list/1100. Consultado em $13 / 05 / 2020$. 